American Journal of Applied Sciences 4 (2): 99-101, 2007

ISSN 1546-9239

(C) 2007 Science Publications

\title{
Effect of Hydroxylated Compounds on Properties and Emission of Palm Biodiesel
}

\author{
Roila Awang and Choo Yuen May \\ Engineering and Processing Division, Malaysian Palm Oil Board, No. 6, Persiaran Institusi \\ Bandar Baru Bangi,43000 Kajang, Selangor, Malaysia
}

\begin{abstract}
The Malaysian Palm Oil Board (MPOB) attempted the search for a viable alternative fuel leading to a possible substitution to the conventional diesel since 1982, using palm oil derived fuel. Numerous studies have shown that most exhaust emission encountered with conventional diesel fuel are reduced with biodiesel,with the exception of nitrogen oxides $\left(\mathrm{NO}_{\mathrm{x}}\right)$. This paper is reported on the effect of hydroxylated compounds on the exhaust gas emission and fuel properties of palm biodiesel. Fuel properties tested are viscosity, specific gravity, energy content, pour point and flash point. No significant decrease in the energy content when $5 \%$ (wt/vol) of hydroxylated compounds were added into palm biodiesel, however the viscosity is increased about $20 \%$. There is a correlation between hydroxyl value of the compound and the reduction of the flame temperature. Higher hydroxyl value resulted in more significant reduction of flame temperature. The engine test run using the most promising compound showed a decrease in the $\mathrm{NO}_{\mathrm{x}}$ emission.
\end{abstract}

Key words: Biodiesel, emission, hydroxylated compound, properties

\section{INTRODUCTION}

Simple fatty acid alkyl esters have numerous uses, including as biodiesel. Biodiesel has higher oxygen content than petroleum diesel, and therefore reduces emissions of particulate matters, hydrocarbons and carbon monoxides. It also reduces sulfur emission due to its low or particularly no sulfur content. However, nitrogen oxides emission increases by about $10-13 \%$ as compared to petroleum diesel ${ }^{[1]}$. Higher emission of $\mathrm{NO}_{\mathrm{x}}$ when biodiesel is used in diesel engine could be due to the high energy (high caloric value) of long chain fatty esters. This may result in the engine heating up to a higher temperature for biodiesel than for petroleum diesel ${ }^{[2]}$. One method of dealing with biodiesel's $\mathrm{NO}_{\mathrm{x}}$ emission is to retard the injection timing of the engine. While effective, this method would entail that each engine be modified before using biodiesel fuel. Another option is the use of fuel additives. However as of to-date no one has a solution to the $\mathrm{NO}_{\mathrm{x}}$ problem via this method yet ${ }^{[3]}$.

The aim of the present work is to investigate the effect of hydroxylated compound on the $\mathrm{NO}_{\mathrm{x}}$ emission and fuel properties of palm biodiesel. This type of compound is selected on the basis that hydroxyl group in the structure may help to incorporate a small amount of water into the fuel which can lower $\mathrm{NO}_{\mathrm{x}}$ emission.

\section{MATERIALS AND METHODS}

Palm biodiesel was prepared using MPOB pilot plant. Typical composition are $45 \%$ of $\mathrm{C}_{16}$ methyl esters, $5 \%$ of $\mathrm{C}_{18}$ methyl esters, $39 \%$ of $\mathrm{C}_{18: 1}$ methyl esters and $10 \%$ of $\mathrm{C}_{18: 2}$ methyl esters. Ethylene glycol di(dihydroxystearate) (DHSAEG), methyl dihydroxystearate (DHSAME) and hydroxylated triglycerides $\left(\mathrm{HTSO}_{2}\right.$ and HTPO) were prepared in the laboratory ${ }^{[4]}$.

\section{Physical properties determination:}

Viscosity: Viscosities of all fuels were determined at $25^{\circ} \mathrm{C}$. A Brookfield viscometer (Brookfield Engineering Laboratories, Inc., Stougton, MA) with adapter was used. Temperaturse of the samples were maintained within $\pm 0.5^{\circ} \mathrm{C}$ by submerging the sample cup in a temperature bath. Samples were placed in the adapter cup, which werethen fixed to the viscometer. The cup was dipped in the constant-temperature bath for a few minutes before taking the viscosity measurements.

Energy content: Gross energy content or heat of combustion of all fuel was determined according to ASTM method D240-92 $2^{[5]}$. A LECO AC 350 automatic oxygen bom calorimeter (LECO Corporation, Michigan, USA) was used. The specific gravity of the fuel was determined using MetlerToledo Densitometer. The fuel temperature was $15^{\circ} \mathrm{C}$. The pour point and flash point of the fuel were determined according to ASTM standard method D97-93 and D93-90 ${ }^{[5]}$, respectively.

Emission test: A horizontal, four stroke, four-cylinder Isuzu 4FB1 diesel engine was used in the experiments without modification. The engine specifications are:

\footnotetext{
Corresponding Author: Dr. Roila Awang, Engineering and Processing Division, Malaysian Palm Oil Board No. 6, Persiaran Institusi, Bandar Baru Bangi, 43000 Kajang, Selangor, Malaysia, Tel: 60389282556, Fax: 603-89266197
} 
type, Isuzu 4FB1, 4-cylinder, 4-stroke, indirect injection; cooling, water; swept vol/stroke (L), 1.817; bore $(\mathrm{mm}), 84$; stroke $(\mathrm{mm}), 82$; compression ratio, 20; nominal power output $(\mathrm{kW})$ at revolutions/mins, 39 at 5,000. A variable speed ranges from 1500 to $3500 \mathrm{rpm}$ with $50 \%$ throttle setting was selected for all tests. A Bosh gas analyzer model ETT 008.36 was used to measure $\mathrm{HC}$ and $\mathrm{CO}$ emissions. A Bacharach model CA300NSX analyzer (Standard version, k-type probe) was used to measure $\mathrm{NO}_{\mathrm{x}}$ concentration.

\section{RESULTS AND DISCUSSION}

Physical properties: Table 1 gives a summary of physical and fuel properties of palm biodiesel and modified biodiesel.

Viscosity and specific gravity: Proper operation of an engine depends on the proper viscosity of the liquid fuel. The viscosity of fuel is important to its flow throw pipelines, injector nozzles and orifices and for atomization of fuel in cylinder. The viscosity data presented in Table 1 show that a slight increase in viscosity was observed after the addition of additives. Viscosity of the fuel gradually increased as the amount of additive increased (Table 2). Similar trend was also observed for specific gravity. Accurate determination of the density, specific gravity of petroleum products are necessary for the conversion of measured volumes to volumes at standard temperatures of $15^{\circ} \mathrm{C}$. These properties however, are uncertain indications of fuel quality unless correlated with other properties. Mullins $^{[6]}$ correlated fuel density with particulate emissions and concluded that increasing density gave increasing particulate emissions.

Energy content: Heat of combustion is a measure of the energy available in a fuel. It is a critical property of fuel intended for use in weight-limited vehicles. The energy content of palm biodiesel and modified palm biodiesel is presented in Table 1. The gross energy content of both palm diesel and modified palm biodiesel is lower than petroleum diesel. Goering et $a l .{ }^{[7]}$ also reported that gross heat content of differently processed vegetable oils was less than that of petroleum diesel. The energy content of modified palm biodiesel was reduced by about $0.1 \%$ to $0.5 \%$ compared to palmdiesel. The energy content decreased as the amount of additive content increased (Table 2).

Pour Point and Flash Point: As shown in Table 1 there was no noticeable difference in pour point when $5 \%$ of the hydroxylated compounds was added into palm biodiesel. Adding DHSA-EG up to $20 \%$ (wt/vol) did not show any difference in pour point of the fuel (Table 2). Flash point measures the tendency of the sample to form a flammable mixture with air under controlled laboratory conditions. This is the only property that must be considered in assessing to overall flammability

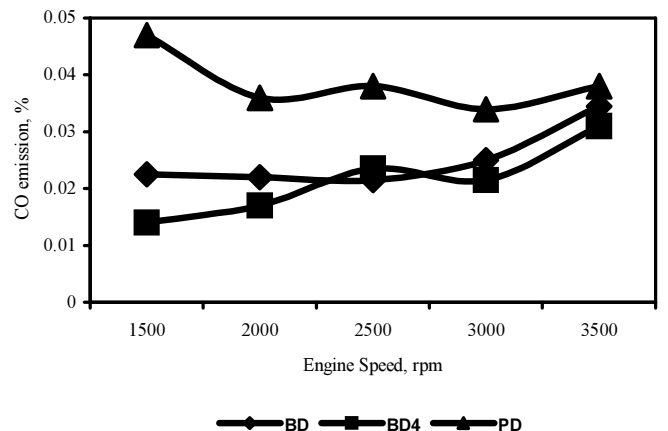

Fig. 1: $\mathrm{CO}$ concentration Vs. engine speed

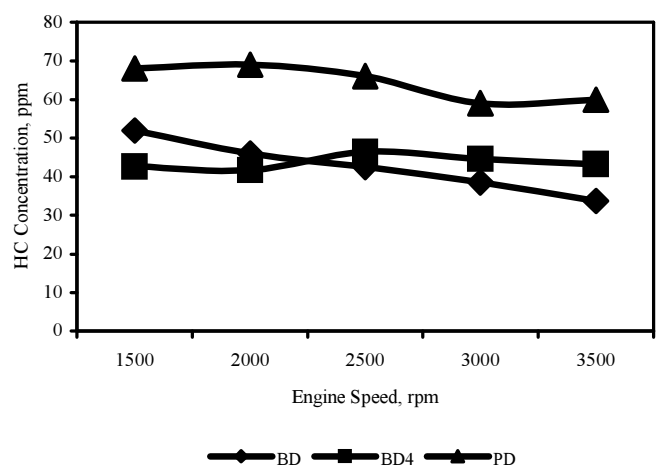

Fig. 2: HC concentration Vs. engine speed

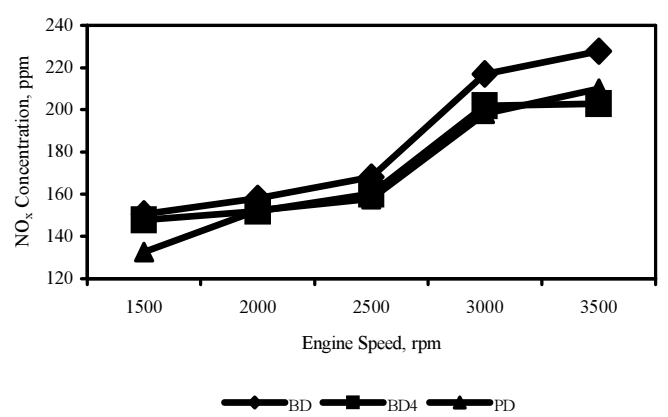

Fig. 3: $\mathrm{NO}_{\mathrm{x}}$ concentration Vs. engine speed

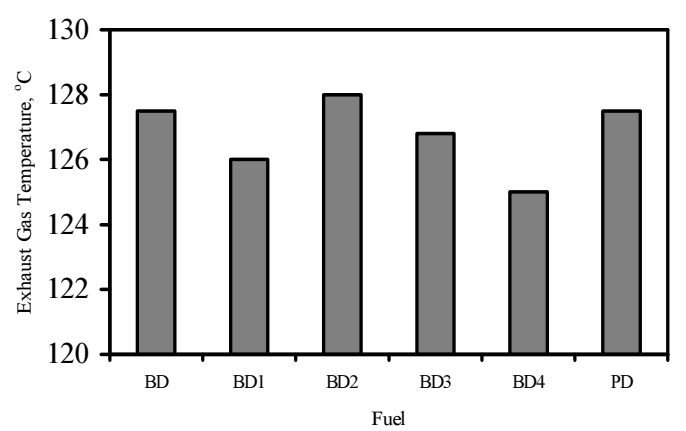

Fig. 4: Exhaust gas temperature for tested fuel 
Table 1: $\quad$ Physical and fuel properties of palm biodiesel and its blended fuel

\begin{tabular}{|c|c|c|c|c|c|}
\hline Fuel Properties & $\mathrm{BD}$ & BD1 & $\mathrm{BD} 2$ & BD3 & BD4 \\
\hline Viscosity, $\mathrm{cP}, 25^{\circ} \mathrm{C}$ & 6.55 & 8.07 & 8.05 & 8.18 & 8.14 \\
\hline Specific Gravity & 0.8722 & 0.8782 & 0.8769 & 0.8778 & 0.8779 \\
\hline Energy Content, $\mathrm{J} / \mathrm{g}$ & 39691 & 39482 & 39631 & 39567 & 39643 \\
\hline Pour Point, ${ }^{\circ} \mathrm{C}$ & 12.0 & 12.0 & 12.0 & 12.0 & 12.0 \\
\hline Flash Point, ${ }^{\circ} \mathrm{C}$ & 175 & 175 & 174 & 175 & 173 \\
\hline Flame Temperature, ${ }^{\circ} \mathrm{C}$ & 906 & 889 & 905 & 900 & 886 \\
\hline \multicolumn{6}{|c|}{$\begin{array}{l}\mathrm{BD}=\text { palm biodiesel, } \mathrm{BD} 1=\text { palm biodiesel containing DHSAME as additive, } \mathrm{BD} 2=\text { palm biodiesel containing } \mathrm{HTSO} 2 \text { as additive, } \mathrm{BD} 3=\text { palm biodiesel containing } \\
\mathrm{HTPO} \text { as additive, } \mathrm{BD} 4=\text { palm biodiesel containing DHSA-EG as additive }\end{array}$} \\
\hline \multicolumn{6}{|c|}{ Effect of DHSA-EG concentration on palm biodiesel properties } \\
\hline [DHSA-EG], \% & Flame Temp. ${ }^{\circ} \mathrm{C}$ & Flash Point, ${ }^{\circ} \mathrm{C}$ & Pour Point, ${ }^{\circ} \mathrm{C}$ & Energy Content, J/g & Specific Gravity \\
\hline 0 & 906.0 & 175.0 & 12.0 & 39691 & 0.8722 \\
\hline 2 & 883.0 & 175.0 & 12.0 & 39668 & 0.8745 \\
\hline 5 & 879.3 & 173.0 & 12.0 & 39643 & 0.8788 \\
\hline 10 & 896.7 & 161.0 & 12.0 & 39495 & 0.8830 \\
\hline 20 & 900.4 & 169.0 & 12.0 & 38502 & 0.8919 \\
\hline
\end{tabular}

Table 3: $\quad$ Exhaust emission of petroleum diesel, palm biodiesel and modified palm biodiesel

\begin{tabular}{llll}
\hline Sample & Exhaust gas emission & & \\
& $-\mathrm{CO}, \%$ & $\mathrm{NO}_{\mathrm{x}}, \mathrm{ppm}$ \\
\hline BD & HC, ppm & 0.034 & 227.6 \\
BD1 & 33.3 & 0.029 & 212.8 \\
BD2 & 45.3 & 0.031 & 215.8 \\
BD3 & 38.9 & 0.030 & 208.5 \\
BD4 & 35.7 & 0.031 & 202.8 \\
PD & 43.3 & 0.037 & 210.0 \\
\hline
\end{tabular}

$\mathrm{PD}=$ petroleum diesel, $\mathrm{BD}=$ palm biodiesel, $\mathrm{BD} 1=$ palm biodiesel containing DHSAME as additive, $\mathrm{BD} 2=$ palm biodiesel containing $\mathrm{HTSO} 2$ as additive, $\mathrm{BD} 3=$ palm biodiesel containing HTPO as additive, BD4= palm biodiesel containing DHSA-EG as additive

hazard of a material. It is used in shipping and safety regulations that define flammable and combustible materials. Flash point can indicate the possible presence of highly volatile and flammable materials in relatively nonvolatile or nonflammable material. Flash point of palm biodiesel was far higher than that of petroleum diesel $^{[8]}$. There was not much variation in flash point for palm biodiesel after the addition of $5 \%$ (wt/vol) hydroxyl compounds. However, a slight decrease in flash point was observed by increasing the concentraion of DHSA-EG from 5 to $20 \%$.

Emission test: Table 3 shows the exhaust gas emission of petroleum diesel, palm biodiesel and modified palm biodiesel at an engine speed of $3500 \mathrm{rpm}$. By adding $5 \%$ of DHSA-EG into palm biodiesel decreased the exhaust $\mathrm{NO}_{\mathrm{x}}$ level from 227 to $202 \mathrm{ppm}$. The difference was mainly due to the reduction in combustion temperature caused by DHSA-EG. Adding DHSA-EG in palm biodiesel did not show any beneficial effect in HCs emissions and CO emissions (Fig. 1-3). Exhaust gas temperature measurements showed variation only between $125-128^{\circ} \mathrm{C}$ for the various fuels (Fig. 4). Lower exhaust temperature for the fuel containing DHSA-EG may be caused by lower burning temperature developed in the combustion chamber.

\section{CONCLUSION}

The effect of hydroxylated compounds on the properties and emissions of palm-biodiesel were systematically investigated in this study. It was found that by adding $5 \%$ of DHSA-EG into palm biodiesel, $\mathrm{NO}_{\mathrm{x}}$ emission was decreased from $227 \mathrm{ppm}$ to 202 ppm. No significant decreased in energy content were observed. Viscosity of the fuel gradually increased as the amount of additive increased.

\section{ACKNOWLEDGEMENT}

The authors would like to thank Director General of MPOB for his permission to publish this paper

\section{REFERENCES}

1. David, Y.Z.C., H.V.G. Jon, L. Lumok, A.J. Lawrence, G. H. Earl and J.M. Stephen, 1996. Fuel properties and emission of soybean oil ester as diesel fuel. J. Amer. Oil Chem. Soc., 73: 1549-1555.

2. Lie, K.J. and C.M. Ho, 2003. In search of $\mathrm{NO}_{\mathrm{x}}$ reductant for biodiesel. Proc 2003 Intl. Palm Oil Congr. Chemistry and Technology Conference, pp: 329-332.

3. Tom, K, 1996. Biodiesel alternative fuel makes inroads but hurdles remain. Inform, 7: 801-815.

4. Roila, A., 2002. Preparation of dihydroxystearic acid esters via chemical method. Completed Project Report, Malaysian Palm Oil Board, Kuala Lumpur.

5. Annual Book of ASTM Standards,1994. American Society for Testing and Materials, Philadelphia.

6. Mullin, P., 1994. New research focuses on identifying fuel properties that influence emissions. Diesel Progress Engine and Drives, pp: 94.

7. Georing, C.E., A.W. Schwab, M.J. Daugherty, E.H. Pryde and A.J. Hoakin, 1982. Fuel properties of eleven vegetables oils. Trans of the ASAE, 25: 1472.

8. Yusof, A., M.A. Hanna and S.L. Cuppett, 1992. Fuel properties of tallow and soybean oil ester. J. Amer. Oil Chem. Soc., 72: 557-1564. 